\title{
Expression of platelet derived growth factor B chain and $\beta$ receptor in human coronary arteries after percutaneous transluminal coronary angioplasty: an immunohistochemical study
}

\author{
Shinichi Tanizawa, Makiko Ueda, Chris $M$ van der Loos, Allard C van der Wal, \\ Anton E Becker
}

\begin{abstract}
Objective-To evaluate whether expression of platelet derived growth factor $B$ (PDGF-B) protein is associated with expression of its receptor protein in human coronary arteries after angioplasty and to identify cells involved.

Background-PDGF is considered an important growth factor in the repair process of the vessel wall after angioplasty. In situ hybridisation has revealed expression of PDGF-A and -B chain messenger ribonucleic acid (mRNA) in human coronary arteries at sites of postangioplasty injury.

Methods-Target and non-target sites of eight coronary arteries were studied immunohistochemically for PDGF-B and PDGF- $\beta$ receptor proteins in relation to macrophages, $T$ lymphocytes, smooth muscle cells, and HLA-DR positive cells. Results-The PDGF-B and PDGF- $\beta$ receptor proteins were expressed in areas with distinct repair, containing $\alpha$ actin negative spindle cells, macrophages and, at later stages, $\alpha$ actin positive smooth muscle cells as well. When the neointima was composed mainly of $\alpha$ actin smooth muscle cells, PDGF-B expression was rare and PDGF- $\beta$ receptor expression

experimental studies it has been suggested that platelet derived growth factor (PDGF) is one of the biological determinants involved. ${ }^{4-7}$ The potential role of PDGF has also been highlighted by its presence in human atherosclerotic lesions. ${ }^{8-10}$ We have recently shown by in situ hybridisation techniques that PDGF-A and $-B$ chain mRNA is expressed in human coronary arteries at sites of lesions after angioplasty (unpublished data). However, from the point of view of potential functional significance, it is essential to know whether the appropriate PDGF receptors are also expressed.

These data may improve our understanding of the postangioplasty wound healing processes in humans, since plaque morphology varies considerably. In some plaques the fibrous cap is dominated by smooth muscle cells, in others by macrophages, while the majority show intermediate varieties. ${ }^{11}$ Furthermore, the type of laceration induced by the angioplasty procedure may also vary markedly..$^{12-15}$ In view of the potential cellular heterogeneity present at the site of angioplasty injury, it is important to obtain information about the types of cell expressing PDGF. To do this, we have conducted a study using immunocytochemical techniques to identify cells expressing the PDGF-B protein and the PDGF- $\beta$ receptor protein.
\end{abstract} was negative.

Conclusions-There is expression of PDGF-B and PDGF- $\beta$ receptor proteins at sites of postangioplasty repair in human coronary arteries. The associated cells are mainly macrophages and $\alpha$ actin negative spindle cells; the latter may be dedifferentiated smooth muscle cells. A link between PDGF expression and the postangioplasty time interval suggests a relation with cell differentiation as part of the maturation of the repair tissue. Mutual expression of both the growth factor and its receptor protein strongly suggests that in humans a PDGF mediated repair process occurs, with involvement of smooth muscle cells and macrophages.

(Heart 1996;75:549-556)

Keywords: restenosis; growth factors; smooth muscle cells; macrophages

The cellular response of the vessel wall after coronary angioplasty in humans is dominated by smooth muscle cells. ${ }^{1-3}$ On the basis of

\section{Methods}

PATIENTS

The study is based on eight different dilated coronary arteries obtained from eight patients who had undergone an initial successful angioplasty, but who subsequently died and came to necropsy. All patients died as a result of ischaemic heart disease. The relevant clinical data are summarised in table 1 .

The target site of the angioplasty procedure was identified by comparing the clinical angiograms with the heart specimens, taking the coronary ostia and bifurcation sites as points of reference. In two patients (case 7, left anterior descending coronary artery; case 8, left circumflex coronary artery) a follow up angiogram did not show evidence of restenosis. In the remaining six patients no follow up angiogram was done. None of the patients had immune deficiency.

\section{HISTOPATHOLOGY AND}

IMMUNOHISTOCHEMISTRY

All necropsies were performed within $3 \mathrm{~h}$ after death. The coronary arteries were removed 
Table 1 Relevant clinical data of eight patients following percutaneous transluminal coronary angioplasty (PTCA)

\begin{tabular}{|c|c|c|c|c|c|c|c|c|}
\hline \multirow[b]{2}{*}{ Case No } & \multirow{2}{*}{$\begin{array}{l}\text { Age } \\
\text { (years) }\end{array}$} & \multirow[b]{2}{*}{ Sex } & \multirow{2}{*}{$\begin{array}{l}\text { Reason } \\
\text { for PTCA }\end{array}$} & \multirow{2}{*}{$\begin{array}{l}\text { Site } \\
\text { of PTCA }\end{array}$} & \multirow{2}{*}{$\begin{array}{l}\text { Interval } \\
\text { PTCA/death }\end{array}$} & \multicolumn{2}{|c|}{$\begin{array}{l}\text { PTCA artery } \\
\text { narrowing }(\% D R)\end{array}$} & \multirow[b]{2}{*}{ Cause of death } \\
\hline & & & & & & pre & post & \\
\hline 1 & 78 & $\mathrm{~F}$ & AMI & RCA (1) & 2 days & 100 & 35 & $\mathrm{CHF} \dagger$ \\
\hline $2^{\star}$ & 70 & $M$ & AMI & LAD (7) & 6 days & 100 & 33 & Cardiac rupture $†$ \\
\hline $3^{\star}$ & 72 & M & AMI & LAD (7) & 14 days & 100 & 42 & CHFt \\
\hline $4^{\star}$ & 67 & $\mathbf{M}$ & AMI & RCA (2) & 28 days & 100 & 27 & $\mathrm{CHF}+$ \\
\hline 5 & 58 & $\mathbf{M}$ & AMI, OMI & LAD (6) & 37 days & 100 & 50 & CHFt \\
\hline $6^{\star}$ & 67 & $\mathbf{M}$ & SAP, OMI & $\mathrm{LAD}(7)$ & 44 days & 90 & 10 & $\mathrm{CHF}+$, pneumonia \\
\hline $7^{\star}$ & 58 & $\mathbf{M}$ & AMI & $\mathrm{LAD}(6)$ & 56 days & 100 & 25 & $\mathrm{CHF}$ \\
\hline 8 & 77 & $\mathrm{~F}$ & UAP, OMI & LCx (11) & 6 months & 99 & 40 & CHF $\ddagger$ \\
\hline
\end{tabular}

AMI, acute myocardial infarction; CHF, congestive heart failure; DR, diameter reduction; LAD, left anterior descending coronary artery; LCx, left circumflex artery; OMI, old myocardial infarction; RCA right coronary artery; SAP, stable angina pectoris; UAP, unstable angina pectoris.

Segment(s) of the coronary arteries that were dilated are shown in parentheses (according to the American Heart Association Committee Report. Circulation 1975; 51 [suppl]: 5-40).

* Material of these patients has been used for in situ hybridisation of PDGF-A and B chain mRNA.

tRelates to initial infarction.

$\ddagger D$ ue to multivessel disease.

from the epicardial surface. The full length of the segments which had contained the balloon and which included the culprit lesion was then identified and the specimen was sliced serially at approximately $1 \mathrm{~mm}$ intervals. In cases 2,3 , 4,6 , and 7 , one slice was fixed in methanolCarnoy's fixative, a second slice was immersed in $4 \%$ paraformaldehyde, and a third slice was snap frozen. This sequence was repeated throughout the total length of the dilated arterial segment. In the remaining cases, a slice fixed with methanol-Carnoy's solution and a second snap frozen slice were repeated throughout the total length of the inflated segment. From the same arterial segment a distal smaller segment, remote from the area that had contained the balloon, was selected as control. The snap frozen samples were sectioned serially at $6 \mu \mathrm{m}$ thickness and fixed in acetone. Every first section was stained with haematoxylin and eosin; the other sections were used for immunocytochemical staining. Adjacent slices in $4 \%$ paraformaldehyde and in Carnoy's fixative were used for the evaluation of the site of angioplasty injury. The identification of angioplasty related injury was based on findings that a laceration continued through several slices and stayed geometrically at almost the same location in the artery. Moreover, the injury extended far beyond the area which contained the culprit lesion. On that basis we were certain that the sections selected for study contained angioplasty induced laceration.

The primary antibodies used are listed in table 2. For the identification of PDGF-B a mouse monoclonal antibody (PGF-007) was used (kindly provided by Mochida
Pharmaceutical Co, Inc, Japan), generated against a 25-amino-acid peptide located near the $\mathrm{COOH}$ terminus of human PDGF-B chain (residues 73 to 97 of mature B chain). Its specificity has been reported. ${ }^{9}$

For the identification of the PDGF- $\beta$ receptor, a mouse monoclonal antibody (PDGFRB2) was used (Oncogene Science). The antibody is raised against porcine PDGF receptor and recognises the extracellular portion of the human PDGF- $\beta$ receptor (not the $\alpha$ receptor). ${ }^{16}$

Sections were incubated at $4^{\circ} \mathrm{C}$ overnight and then subjected to a three-step staining procedure, using the streptavidin-biotin complex method for colour detection. The other antibodies (see table 2) were incubated at room temperature for $1 \mathrm{~h}$. Some sections of each case were double stained with HAM-56 (immunoglobulin $\mathrm{M}$ ) and Leu 4 (immunoglobulin G1), HLA-DR (immunoglobulin G2a) and Leu 4 (immunoglobulin G1) or 1A4 (immunoglobulin G2a) and HAM-56 (immunoglobulin $\mathrm{M}$ ), according to procedures previously reported. ${ }^{17}$

The specificity of the results obtained with PGF-007 and PDGFR-B2 was checked by omitting the primary antibodies and by using one irrelevant mouse immunoglobulin $\mathrm{G}$ antibody. Moreover, PGF-007 neutralisation with a relevant peptide (kindly provided by Mochida Pharmaceutical Co, Japan) was performed on frozen sections of human coronary arteries with advanced atherosclerosis, normal lung tissue (alveolar macrophages), and normal brain tissue (glial cells).

All single stained sections were counterstained with haematoxylin.

Table 2 Source, specification, and working dilution of the antibodies

\begin{tabular}{|c|c|c|c|c|}
\hline Designation & Specificity & Cell identified & Source/reference & Working dilution \\
\hline PGF-007 & $\begin{array}{l}\text { Amino acid residues } 73 \text { to } 97 \text { of mature } \\
P D G F-B \text { chain }\end{array}$ & PDGF-B presenting cells & Ross $e t a l^{\varphi}$ & $1: 2000$ \\
\hline PDGF-R-B2 & Epitope present in the extracellular part of & PDGF- $\beta$ receptor & OS & \\
\hline & the PDGF- $\beta$ receptor & $\begin{array}{l}\text { presenting cells } \\
\text { Monocytes, macrophages } \\
\text { some endothelial cells }\end{array}$ & $\begin{array}{l}\text { Rönnst } \\
\text { Dako }\end{array}$ & $\begin{array}{l}1: 200 \\
1: 50^{\star}\end{array}$ \\
\hline $\begin{array}{l}\text { Leu } 4 \\
1 A 4 \\
1 A 4-D R\end{array}$ & $\begin{array}{l}\text { CD3 } \\
\alpha \text { smooth muscle actin }\end{array}$ & $\begin{array}{l}\text { T cells } \\
\text { Smooth muscle cells } \\
D^{+} \text {cells }\end{array}$ & $\begin{array}{l}\text { B \& D } \\
\text { Dako }\end{array}$ & $\begin{array}{l}1: 10^{\star} \\
1: 50^{\star} \\
1 \cdot 25^{\star}\end{array}$ \\
\hline
\end{tabular}

OS, Oncogene Science (Uniondale, New York, USA); Dako, Dako Laboratories (Glostrup, Denmark); B \& D, Becton and Dickinson (Mountain View, California, USA). 

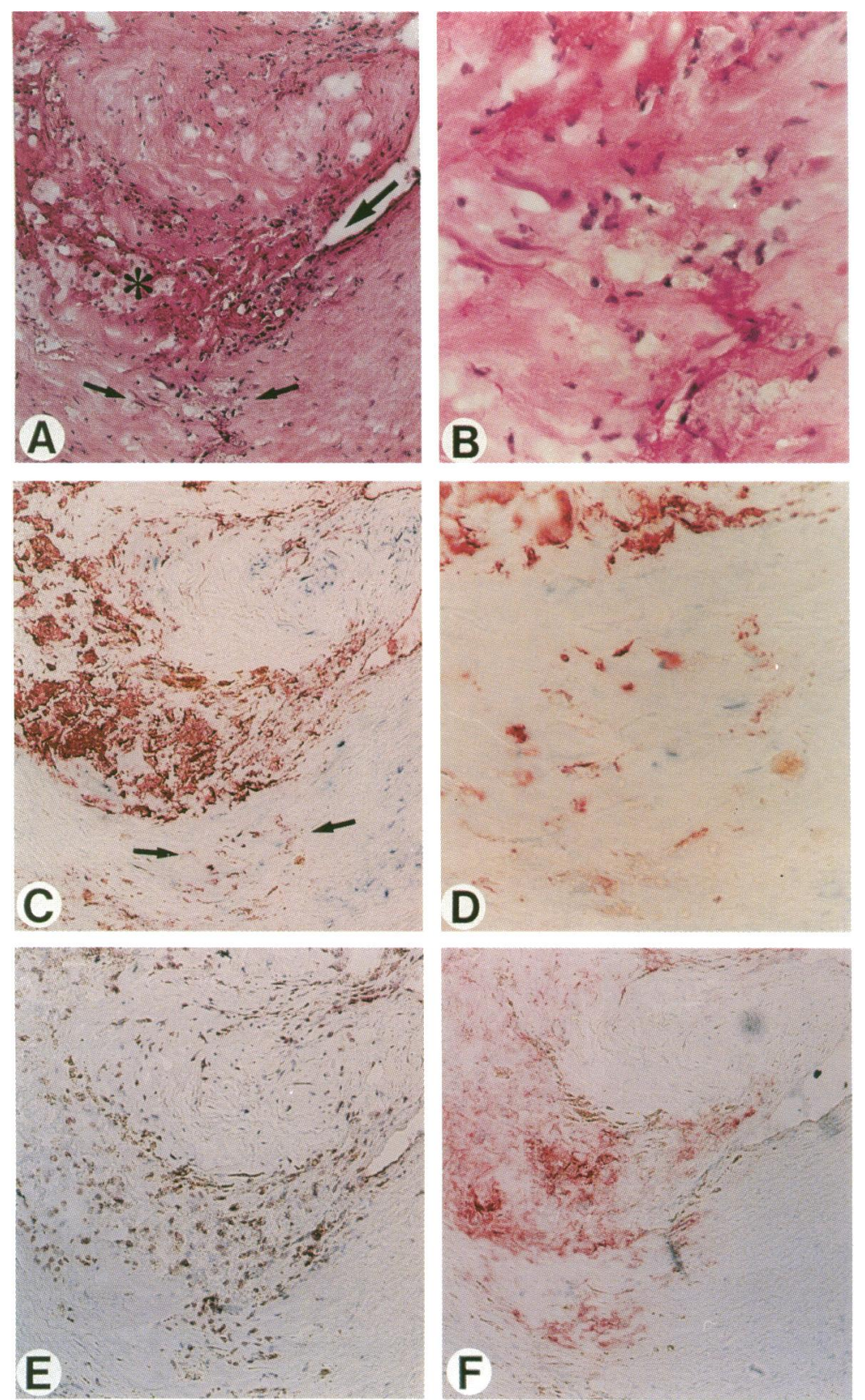

Figure 1 Micrographs of a postangioplasty injury site with a fissure into an atheroma, 14 $d$ after PTCA. (A) Fissure (arrow) into an atheroma with intraplaque haemorrhage amid mononuclear cells (asterisk). The area delineated by the two small arrows is shown in higher magnification in (B). (B) Haematoxylin-eosin stain shows mononuclear cells and spindle cells immediately adjacent to the tear. (C) Immunodouble stain with an antimacrophage antibody (HAM-56: red) and an anti- $\alpha$ actin antibody (1A4: blue). At the site of plaque fissure, a large number of macrophages is seen. In the adjacent preexisting tissue, there are macrophages, smooth muscle cells, and (unstained) spindle cells. The area delineated by arrows is compatible with that shown in panels $(A)$ and $(B)$ and it is shown in higher magnification in (D). (D) Macrophages are stained; a few smooth muscle cells are faintly positive, but the majority of spindle cells do not stain with $1 A 4$ or HAM-56. (E) PDGF-B stain. The macrophages which are seen along the plaque fissure stain positive. In the pre-existing adjacent tissue, macrophages, a proportion of the spindle cells (indicated by arrows in A), and some smooth muscle cells stain positive. (F) PDGF- $\beta$ receptor stain. A proportion of macrophages at the area of plaque fissure shows positive staining. In the pre-existing adjacent tissue PDGF- $\beta$ receptor positive cells correlate with macrophages and spindle cells (indicated by arrows in $A$ ); smooth muscle cells do not stain. Magnification $(A, C, E$ and $F), \times 61 \cdot 5 ;(B$ and $D), \times 196$.

\section{Results}

Each of the eight dilated coronary arteries revealed pre-existing advanced atherosclerotic plaques at the target site. Wall laceration limited to the intima had occurred in six and had extended into the media in two.

TARGET SITE: INTIMAL INJURY

The artery at $2 \mathrm{~d}$ after angioplasty had a laceration at the site of a lipid-rich plaque. The site contained a thrombus extending into the ruptured plaque. HLA-DR positive monocytes/ macrophages were present alongside the atheroma and within the thrombus. There was no staining for PDGF-B and PDGF- $\beta$ receptor. The adjacent pre-existing tissue contained spindle cells, defined as cells not expressing $\alpha$ actin and negative for HAM-56, and a few cells identified as smooth muscle cells on the basis of a positive stain for $\alpha$ actin. A few spindle cells were HLA-DR positive. None of the cells stained for PDGF-B or for the PDGF- $\beta$ receptor.

The artery at $6 \mathrm{~d}$ after angioplasty had a tear which also extended into an atheromatous area. The lesion contained many macrophages, which were mostly HLA-DR positive. A proportion of macrophages within the ruptured atheroma, and in particular those alongside the calcified border, stained positive for PDGF-B. However, none of the macrophages stained for the PDGF- $\beta$ receptor. The adjacent pre-existing tissue contained macrophages and spindle cells, most of which were HLA-DR positive. A few smooth muscle cells were identified. Some of the macrophages were positive for PDGF-B and the PDGF- $\beta$ receptor. The area which contained spindle cells stained positive for the PDGF- $\beta$ receptor, but not for PDGF-B. The localisation was similar to that of the HLA-DR positive cells. None of the smooth muscle cells expressed PDGF-B or the receptor.

The artery at $14 \mathrm{~d}$ after angioplasty presented a ruptured plaque which contained a large number of macrophages amid plaque haemorrhage (fig 1). The macrophages stained positive for PDGF-B and some also stained positive for the PDGF- $\beta$ receptor (fig 1). These cells were HLA-DR positive. The adjacent pre-existing tissue contained macrophages, spindle cells, and smooth muscle cells. Most macrophages were HLA-DR positive. Only an occasional spindle cell and smooth muscle cell showed HLA-DR positive staining. The areas that stained positive for PDGF$B$ coincided with those that stained positive for HLA-DR. PDGF- $\beta$ receptor was expressed in the area containing macrophages and spindle cells, but no positivity for the PDGF- $\beta$ receptor was found in an area containing mainly smooth muscle cells.

The arterial segment obtained at $28 \mathrm{~d}$ after angioplasty showed remnants of plaque thrombus, but there were now also spindle cells amid macrophages. The vast majority of these cells expressed HLA-DR. Most macrophages expressed PDGF-B, whereas only a proportion of the spindle cells expressed PDGF-B. Some of the macrophages and spindle cells were positive for the PDGF- $\beta$ receptor. In the adjacent pre-existing tissues the cellular components were similar to those seen at $14 \mathrm{~d}$. At this stage some of the smooth muscle cells also expressed PDGF- $\beta$ receptor positivity.

The segment at 37 days after angioplasty showed a superficial injury of a lipid-rich lesion. Macrophages and spindle cells were present and occasionally a smooth muscle cell 
Figure 2 Micrographs of a postangioplasty injury site limited to the intima, $56 \mathrm{~d}$ after angioplasty. (A) Neointima (asterisk) at the site of injury (I, preexisting intima). (B)

Immunodouble stain with an antimacrophage antibody (HAM-56: red) and an anti-actin antibody (1A4: blue). The neointima is composed mainly of smooth muscle cells; only occasional macrophages are seen. $(C)$ $P D G F-B$ stain. In the neointima smooth muscle cells stain positive; a few macrophages in the

neointima and in the preexisting intima also show positivity. (D) PDGF- $\beta$ receptor stain. The neointimal smooth muscle cells are negative; a few cells in the pre-existing intima show positive staining. Magnification $\times 148$.

Figure 3 Micrographs showing a postangioplasty injury site with medial laceration, $44 d$ after angioplasty. (A) The laceration has extended from laceration has extended fror media (M). Fibrocellular tissue (asterisks) has filled the gap. The boxed area is enlarged in (B). (B) $A$ higher magnification shows high cellularity in the neointima and the adjacent pre-existing intima. (C) Immunodouble stain with an antimacrophage antibody (HAM-56: red) and an (HAM-56: red) and an anti-actin antibody ( $1 A 4:$
blue). The fibrocellular reaction is composed mainly of macrophages and smooth muscle cells. The boxed area is enlarged in (D). (D) Macrophages and unstained spindle cells with some neointimal smooth muscle cells are seen (compare to $B$ ). (E) PDGF-B stain. The same area shown boxed in (C). Smooth muscle cells and macrophages in the fibrocellular tissue stain positive. In the pre-existing intima, macrophages and some spindle cells stain positive. (F), PDGF- $\beta$ receptor stain. The same boxed area shown in $(C)$ Within the fibrocellular tissue, macrophages and some smooth muscle cells are positive. Within the preexisting intima,

macrophages and a

proportion of spindle cells stain positive. There are more PDGF- $\beta$ receptor positive spindle cells than positive spindle cells than (compare with $E$ ) Magnification ( $A, C, E$ and $F), \times 66$; $(B$ and $D), \times$ 168.
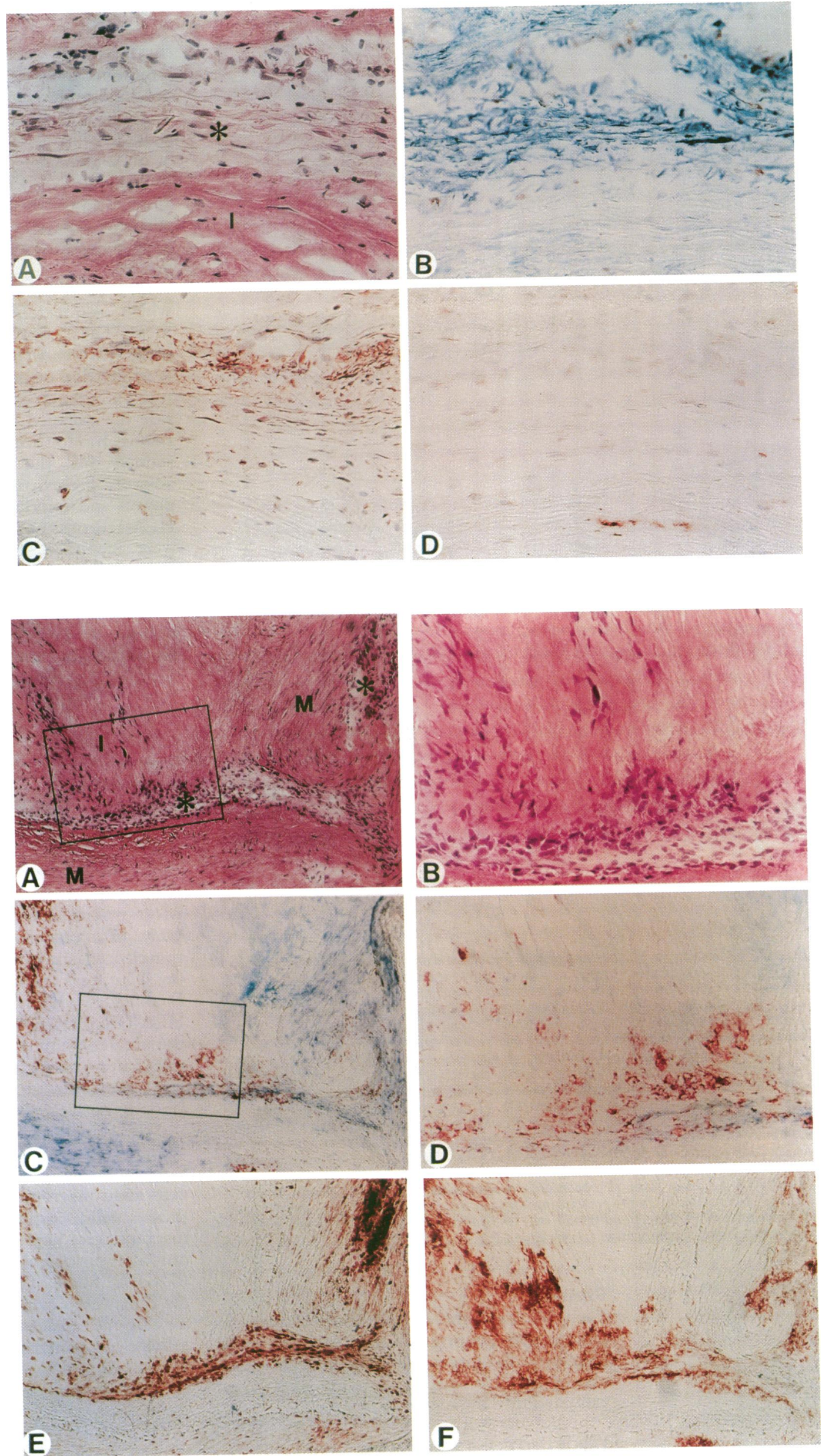
Figure 4 Micrographs showing a postangioplasty injury site with medial laceration, six months after PTCA (A) Fibrocellular tissue (asterish) at the site of medial laceration which separates the media $(M)$ from the internal elastic lamina (EL). The

fibrocellular tissue is present also at the luminal site (asterisk). (B)

Immunodouble stain with an antimacrophage antibody (HAM-56: red) and an anti-smooth muscle $\alpha$ actin antibody (1A4: blue). The fibrocellular tissues (asterisks), sandwiched between the intima (I) and media (M) and at the luminal site, are composed mainly of smooth muscle cells. (C) PDGF-B stain. Some cells in the fibrocellular tissue show positive staining, but the majority are negative. (D) $P D G F-\beta$ receptor stain. No positive staining in the fibrocellular tissue. Magnification $\times 75$.
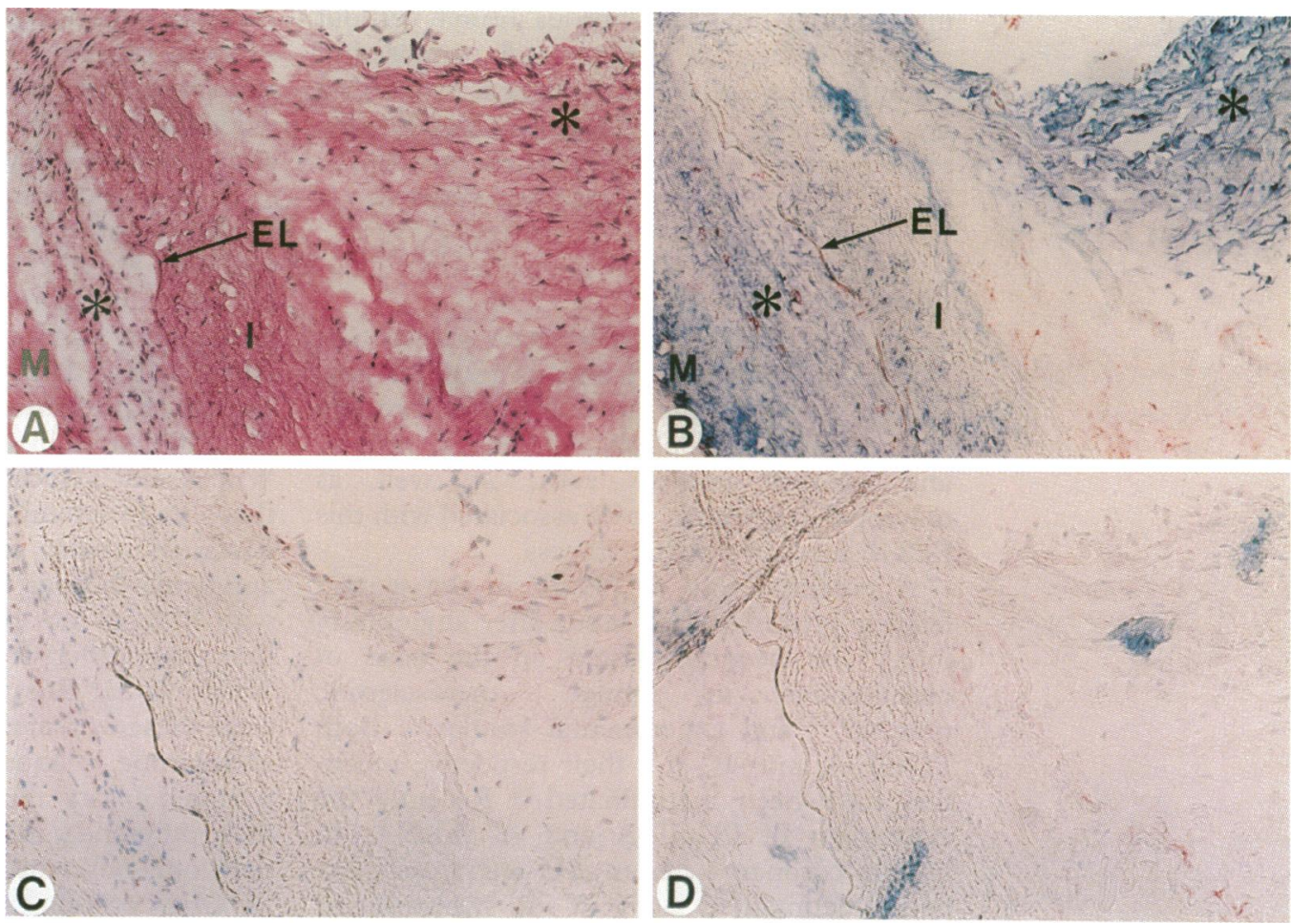

was identified. Macrophages and spindle cells were HLA-DR positive. Positivity for PDGF$B$ and the PDGF- $\beta$ receptor was found in the same area which contained macrophages and spindle cells and the occasional smooth muscle cell. Within the adjacent pre-existing tissues macrophages, spindle cells and a few smooth muscle cells were encountered. The majority of these cells expressed HLA-DR. Most macrophages and some spindle cells expressed both PDGF-B and the PDGF- $\beta$ receptor. A few smooth muscle cells expressed PDGF-B or PDGF- $\beta$ receptor or both.

The artery obtained at 56 days showed a superficial injury, covered by a distinct neointimal cap composed mainly of smooth muscle cells with only a few macrophages (fig 2 ). The latter were positive for HLA-DR, whereas only a few of the smooth muscle cells were HLADR positive. PDGF-B positivity was distinct and present in the same areas containing macrophages and smooth muscle cells (fig 2). PDGF- $\beta$ receptor positivity was much less, but when present occurred in areas with macrophages. Smooth muscle cells were negative for PDGF- $\beta$ receptor at this stage. In the adjacent pre-existing tissues, macrophages, spindle cells, and smooth muscle cells were encountered, with no HLA-DR staining among smooth muscle cells. Positivity for PDGF-B was encountered in the regions that coincided with the localisation of spindle cells, smooth muscle cells, and macrophages. The PDGF- $\beta$ receptor was occasionally positive and related to areas containing macrophages and spindle cells. Smooth muscle cells were negative for the receptor.

$\mathrm{T}$ cells were distinct at the site of injury and always associated with macrophages. They were most pronounced at 28 and $37 \mathrm{~d}$, but less so at $56 \mathrm{~d}$.
INTIMAL/MEDIAL INJURY

The artery harvested at $44 \mathrm{~d}$ after angioplasty showed fibrocellular proliferation filling the laceration site. It was composed mainly of smooth muscle cells and macrophages (fig 3). Most macrophages and a proportion of smooth muscle cells were HLA-DR positive. Moreover, PDGF-B was strongly positive in the areas containing both macrophages and smooth muscle cells. Macrophages were strongly positive also for the PDGF- $\beta$ receptor, and some of the smooth muscle cells also stained positive for the receptor. The adjacent pre-existing tissue contained macrophages which were distinctly positive for both PDGF$B$ and the PDGF- $\beta$ receptor. Spindle cells, present in the pre-existing intima, were only occasionally positive for PDGF-B, but more cells stained positive for the PDGF- $\beta$ receptor. The smooth muscle cells of the pre-existing media occasionally expressed PDGF-B, but there was no positivity for the PDGF- $\beta$ receptor (fig 3).

The artery obtained at six months after angioplasty showed an extensive fibrocellular proliferation at the site of medial injury. The tissue was composed mainly of smooth muscle cells (fig 4). Only an occasional PDGF-B positive cell was seen; there was no staining reactivity for the PDGF- $\beta$ receptor. Some smooth muscle cells were HLA-DR positive. In the adjacent preexistent tissues spindle cells were negative for PDGF-B, with only an occasional spindle cell showing positivity for the PDGF- $\beta$ receptor. Smooth muscle cells, both in the intima and the media, were occasionally positive for PDGF-B, but none stained for the PDGF- $\beta$ receptor.

DISTAL NON-TARGET SITE

These sites contained diffuse intimal thicken- 
ing or mildly thickened fibrous intima, without appreciable lipid depositions and composed of smooth muscle cells amid collagen, with only a few scattered macrophages. Occasionally, some macrophages stained positive for PDGF$\mathrm{B}$; PDGF- $\beta$ receptor staining was negative.

\section{Discussion}

In this study in humans we have shown that PDGF-B chain protein and its receptor protein are present at the site of injury in coronary arteries after angioplasty. Moreover, spindle and smooth muscle cells, as well as macrophages, appear to be associated with this PDGF mediated repair process.

A potential role of PDGF in the wound healing processes that occur after angioplasty injury has been suggested on the basis of observations in human atherosclerotic plaques $^{8-10}$ and experimental studies. ${ }^{4-7}$ Both PDGF-A and $-B$, and their respective receptors have been incriminated. ${ }^{48}$ Recently the expression of PDGF-A and -B mRNAs in human coronary arteries after angioplasty has been documented using in situ hybridisation techniques (unpublished data). The present study has focused on the expression of PDGF$\mathrm{B}$ and the PDGF- $\beta$ receptor proteins only, because reliable monoclonal antibodies against PDGF-A and the PDGF- $\alpha$ receptor are not available to us.

PDGF-B PROTEIN

In this study, in the earliest stages after angioplasty available, all specimens had lacerations limited to the intimal plaque. In these instances monocytes/macrophages appear as the main source of PDGF-B protein. The appearance of HLA-DR positive monocytes/ macrophages at two days after injury indicates active involvement, but at that stage the cells were still negative for PDGF-B. However, at six days after injury a proportion of macrophages located immediately adjacent to the tear expressed PDGF-B. Arterial segments harvested at subsequent later stages after angioplasty contained a higher ratio of PDGF$B$ positive versus PDGF-B negative macrophages, both at the injury site proper as well as in the adjacent pre-existing tissues. Late after angioplasty the number of macrophages was reduced and likewise the number of PDGF-B chain positive macrophages was minimal.

In addition to macrophages it appeared also that spindle cells (defined as cells not expressing $\alpha$ actin and negative with HAM-56) and smooth muscle cells ( $\alpha$ actin positive) of the adjacent pre-existing tissue expressed PDGFB protein; a phenomenon which in this study was identified first at 14 days after angioplasty. Once spindle cells appeared in the reactive tissue after angioplasty injury (at 28 days in this study) they also expressed PDGF-B protein. The same applied for smooth muscle cells, but their appearance in the neointima occurred at a later stage. Spindle cells were not identified in the neointima of the cases studied 44 days, 56 days, and six months after angioplasty, most probably because they had differentiated into $\alpha$ actin containing smooth muscle cells. ${ }^{2318}$ Smooth muscle cells within the neointima in this series were positive for PDGF-B for a considerable time, but at 6 months only an occasional positive cell was seen.

Previous immunohistochemical studies of human atherosclerotic plaques by Ross et al ${ }^{9}$ and Katsuda et al ${ }^{10}$ and of human wound healing tissue by Reuterdahl et $a l^{19}$ using the same monoclonal antibody PGF-007 as used in this study, showed that PDGF-B protein was expressed predominantly by macrophages. On the other hand, in situ hybridisation studies by Wilcox and associates ${ }^{8}$ led them to conclude that the predominant cell types expressing PDGF-B chain mRNA are mesenchymalappearing intimal cells and endothelial cells, with little or no expression in macrophages. Our study differs from the studies reported by Wilcox et al, ${ }^{8}$ Ross et al, ${ }^{9}$ and Katsuda et al ${ }^{10}$ since these workers investigated the native atherosclerotic plaque, while we focused on postangioplasty repair processes. In view of these differences in study design, it is of interest that our observations strongly suggest that PDGF-B protein can be expressed by a variety of cells. The differences noted with previous studies could relate to differences in the type of tissue studied.

\section{PDGF- $\beta$ RECEPTOR PROTEIN}

In the pre-existing tissues immediately adjacent to the site of injury, the expression of the PDGF- $\beta$ receptor appeared first on spindle cells and macrophages. This phenomenon was seen as early as six days after injury. In contrast, smooth muscle cells of the adjacent preexistent tissue did not express PDGF- $\beta$ receptor at an early stage; positive cells were seen in the cases obtained at 28 and 37 days after angioplasty.

In the repair tissue at sites of injury limited to an atherosclerotic plaque, the PDGF- $\beta$ receptor protein was expressed in the same area which contained macrophages. Once spindle cells were present in the repair tissue at the site of intimal injury, some of them also expressed the receptor. In the specimen with intimal injury at 37 days, a substantial number of spindle cells was positive for the PDGF- $\beta$ receptor. In the specimen with medial injury at 44 days, the main cellular component of the repair tissue was identified as smooth muscle cell, and these cells expressed the PDGF- $\beta$ receptor. At a later stage, however, smooth muscle cells within the repair tissue were negative for the PDGF- $\beta$ receptor, both at the site of intimal injury and at sites of injury extending into the media.

Although previous studies in humans ${ }^{819-23}$ and in experimental animals ${ }^{24-26}$ have shown that different cells are capable of expressing the PDGF- $\beta$ receptor, the present study is the first to demonstrate this phenomenon in human coronary arteries after angioplasty. The present findings suggest that the dominant cell type that expresses the PDGF- $\beta$ receptor in postangioplasty repair tissue differs, depending on the type of injury inflicted-for instance whether the laceration 
is limited to the intima or extends into the media - and possibly also on the stage of the repair process. In previous work we have shown that the cellular response after angioplasty is different when the injury is limited to the atherosclerotic plaque or extends into the media. ${ }^{15} 27$ We have shown also that at the site of medial injury dedifferentiation of smooth muscle cells occurs very soon after the injury, with reappearance of $\alpha$ actin positive cells at later stages of repair. ${ }^{18}$ The present study suggests that smooth muscle cells in the repair tissue express PDGF- $\beta$ receptor only transiently during the evolution of the healing process after angioplasty. Rubin and coworkers ${ }^{21}$ investigated the expression of PDGF- $\beta$ receptors in human blood vessels with abnormal vascular cell proliferation and concluded that a pronounced expression of PDGF- $\beta$ receptors was seen on vascular smooth muscle cells in rejected kidneys, atherosclerotic carotid plaques, and chronic synovitis. Recently they have also reported that PDGF- $\beta$ receptors are expressed by vascular smooth muscle cells in healing wounds of human skin. ${ }^{19}$ Our observations at least partially support these findings, but seem to indicate that $\alpha$ actin negative spindle cells play a more important role in expressing PDGF- $\beta$ receptor. This observation endorses the findings of Wilcox et $a l^{8}$ who found PDGF receptor mRNA expression in mesenchymal-appearing intimal cells obtained from carotid arteries in humans. There is a real possibility of course that these spindle cells are basically derivatives of smooth muscle cells. ${ }^{18}$ Moreover, our observations in cases with neointimal proliferation further suggest that once spindle cells or smooth muscle cells differentiate into a matured phenotype they no longer express the PDGF- $\beta$ receptor protein. This is of considerable interest since one could argue that at that stage PDGF is no longer actively involved as a growth factor in the wound healing process. In fact, one may hypothesise that the sooner the spindle cells or synthetic smooth muscle cells differentiate towards a more contractile phenotype, the sooner the proliferative response will come to a halt.

The mechanism involved in the induction of the receptor on the pre-existing spindle cells remains to be elucidated. However, the presence of activated macrophages at an early stage creates the possibility that these cells could act as intermediary by releasing cytokines like TGF- $\beta$, which is a potential inducer for the PDGF- $\beta$ receptor. ${ }^{28}$ In reactive cells, both at the injury site itself and in the immediately adjacent tissues, activated macrophages and $\mathrm{T}$ lymphocytes were always closely associated with spindle cells. This suggests active cellular interaction with a key role for PDGF. The results of a recent clinical trial, in which a PDGF antagonist was shown to reduce restenosis after PTCA, also support the concept that the postangioplasty repair tissue is PDGF mediated. ${ }^{29}$

STUDY LIMITATIONS

In interpreting the findings it should be born in mind that PDGF-B protein and the PDGF$\beta$ receptor protein are expressed in native atherosclerotic lesions. ${ }^{91021}$ Hence the presence of the ligand and the receptor proteins at the site of injury could reflect a pre-existing condition rather than upregulation due to the insult. However, the appearance of the PDGF- $\beta$ receptor on cells within the repair tissue strongly suggests "new" rather than "old" expression.

Similarly, it may be important that the injurious effect of the angioplasty procedure may differ from one lesion to another and that the procedure will affect pre-existing coronary atherosclerotic plaques with different morphologies. Hence, potential differences in the expression of PDGF-B protein and the PDGF- $\beta$ receptor may occur. In other words, the expression of PDGF-B chain protein and the PDGF- $\beta$ receptor protein may not necessarily be the same in all instances after angioplasty.

Caution is warranted, moreover, because the number of observations is limited to only eight time points and most of the angioplasty sites in this study had injury affecting an advanced atherosclerotic plaque. Thus further studies with more cases and different postangioplasty morphologies are needed to validate our observations.

During the course of this study Sinichi Tanizawa was a Research Fellow from the Osaka City University Medical School

1 Essed CE, van den Brand M, Becker AE. Transluminal coronary angioplasty and early restenosis. Fibrocellular
occlusion after wall laceration. Br Heart $\mathcal{f} 1983 ; 49: 393-6$. 2 Ueda M, Becker AE, Tsukada T, Numano F, Fujimoto T. Fibrocellular tissue response after percutaneous transluminal coronary angioplasty. An immunocytochemical analysis of the cellular composition. Circulation 1991; 83:1327-32.

3 Wanibuchi H, Ueda $M$, Dingemans KP, Becker AE. The response to percutaneous transluminal coronary angioplasty: an ultrastructural study of smooth muscle cells plasty: an ultrastructural study of smooth muscle cells

4 Majesky MW, Reidy MA, Bowen-Pope DF, Hart CE, Wilcox JN, Schwartz SM. PDGF ligand and receptor Wilcox JN, Schwartz SM. PDGF ligand and receptor gene expression during

5 Ferns GAA, Raines EW, Sprugel KH, Motani AS, Reidy $M A$, Ross R. Inhibition of neointimal smooth muscle accumulation after angioplasty by an antibody to PDGF. Science 1991;253:1129-32.

6 Jawien A, Bowen-Pope DF, Lindner V, Schwartz SM, Clowes AW. Platelet-derived growth factor promotes smooth muscle migration and intimal thickening in a rat model of balloon angioplasty. $\mathcal{f}$ Clin Invest 1992;89: 507-11.

7 Jackson CL, Raines EW, Ross R, Reidy MA. Role of endogenous platelet-derived growth factor in arterial smooth muscle cell migration after balloon catheter injury. Arterioscler Thromb 1993;13:1218-26.

8 Wilcox JN, Smith KM, Williams LT, Schwartz SM, Gordon D. Platelet-derived growth factor mRNA detection in human therosclerotic plaques by in situ hybridization. $\mathcal{F}$ Clin Invest 1988;82:1134-43.

9 Ross R, Masuda J, Raines EW, Gown AM, Katsuda S, Sasahara $M$, et al. Localization of PDGF-B protein in macrophages in all phases of atherogenesis. Science 1990; 248:1009-12.

10 Katsuda S, Coltrera MD, Ross R, Gown AM. Human atherosclerosis. IV. Immunocytochemical analysis of cell activation and proliferation in lesions of young adults. Am $\mathcal{H}$ Pathol 993;142:1787-93.

11 Van der Wal AC, Becker AE, van der Loos CM, Tigges AJ, Das PK. Fibrous and lipid-rich atherosclerotic plaques are part of interchangeable morphologies related to inflammation: a concept. Coron Artery Dis 1994;5:463-9.

2 Colavita PG, Ideker RE, Reimer KA, Hackel DB, Stack RS. The spectrum of pathology associated with percutaneous transluminal coronary angioplasty during acute

13 Kohchi K, Takebayashi S, Block PC, Hiroki T, Nobuyoshi $M$. Arterial changes after percutaneous transluminal coronary angioplasty. Results at autopsy. $\exists \mathrm{Am}$ Coll Cordiol 1987;10:592-9. 
14 Ueda $M$, Becker AE, Fujimoto T, Tsukada $T$. The early phenomena of restenosis following percutaneous transluminal coronary angioplasty. Eur Heart $f$ 1991;12:937-45.

15 Naruko T, Ueda M, Becker AE, Tojo O, Teragaki M, Takeuchi $\mathrm{K}$, et al. Angiographic-pathologic correlations after elective percutaneous transluminal coronary angioplasty. Circulation 1993;88:1558-68.

16 Rönnstrand L, Terracio L, Claesson-Welsh L, Heldin CH, Rubin K. Characterization of two monoclonal antibodies reactive with the external domain of the platelet-derived growth factor receptor. 7 Biol Chem 1988;263:10429-35.

17 Van der Loos CM, Becker AE, van den Oord JJ. Practical suggestions for successful immunoenzyme double-staining experiments. Histochem $\mathcal{f} 1993 ; 25: 1-13$.

18 Ueda M, Becker AE Naruko T, Kojima A Smooth muscle cell de-differentiation is a fundamental change preceding wound healing after percutaneous transluminal ceding wound healing after perutaneous transluminal coron

19 Reuterdahl C, Sundberg C, Rubin K, Funa K, Gerdin B Tissue Tissue localizacion of $\beta$ receptors for platelet-derived growth factor and platelet-derived growth factor B chain during wo wo

20 Hermansson $M$, Nistér $M$, Betsholtz $C$, Heldin $\mathrm{CH}_{\text {, }}$ Westermark B, Funa K. Endothelial cell hyperplasia in human glioblastoma: coexpression of $\mathrm{mRNA}$ for plateletderived growth factor (PDGF) B chain and PDGF recepderived growth factor (PDGF) B chain and PDGF receptor suggests autocrine growth

21 Rubin K, Tingström A, Hansson GK, et al. Induction of $B$ type receptors for platelet-derived growth factor in vascular inflammation: possible implications for developments of vascular proliferative lesions. Lancet 1988;i:1353-6.

22 Reuterdahl C, Tingström A, Terracio L, Funa K, Heldin
$\mathrm{CH}$, Rubin K. Characterization of platelet-derived growth factor $\beta$-receptor expressing cells in the vasculature of human rheumatoid synovium. Lab Invest 1991;64:321-9.

23 Tingström A, Reuterdahl C, Lindahl P, Heldin CH, Rubin $K$. Expression of platelet-derived growth factor- $\beta$ receptors on human fibroblasts: regulation by recombinan platelet-derived growth factor-BB, IL-1, and tumor necrosis factor- $\alpha$. $f$ Immunol 1992;148:546-54

24 Smits A, Hermansson M, Nistér M, et al. Rat brain capillary endothelial cells express functional PDGF B-type receptors. Growth Factors 1989;2:1-8.

25 Kraiss LW, Raines EW, Wilcox JN, et al. Regional expression of the platelet-derived growth factor and its receptors in a primate graft model of vessel wall assembly. $f$ Clin Invest 1993;92:338-48.

26 Yan X-Q, Brady G, Iscove NW. Platelet-derived growth factor (PDGF) activates primitive hematopoietic precursors (pre-CFCmulti) by up-regulating IL-1 in PDGF receptor-expressing macrophages. F Immunol 1993;150: $2440-8$.

27 Ueda M, Becker AE, Fujimoto T. Pathological changes induced by repeated percutaneous transluminal coronary induced by repeated percutaneous trans

28 Gronwald RGK, Seifert RA, Bowen-Pope DF. Differential regulation of expression of two platelet-derived growth regulation of expression of two platelet-derived growth f Biol Chem 1989;264:8120-5.

29 Maresta A, Balducelli M, Cantini L, et al. for the STARC investigators. Trapidil (triazolopyrimidine), a plateletinvestigators. Trapidil (triazolopyrimidine), a platelet-
derived growth factor antagonist, reduces restenosis after percutaneous transluminal coronary angioplasty. Results of the randomized, double-blind STARC study Circulation 1994;90:2710-5. 